\title{
The sound of placards
}

Jesse Ash

Royal College of Art

Jesse Ash is an artist based in London working with painting, collage, writing,

performance, sculpture and film to explore perspectives on political history. His work has been exhibited widely in commercial and public presentations including Arnolfini,

Bristol; The Swedish Contemporary Art Foundation, Stockholm; Museo Marino Marini, Florence; Thaddaeus Ropac, Paris; Tulips and Roses, Brussels/Vilnius; Kadist

Foundation, Paris; CA2M, Madrid; Mendes Wood DM, Sao Paolo; Tanya Bonakdar, New York City; Monitor Gallery, Rome. He completed his Ph.D. in 2011 on the subject of the political agency of rumour at Goldsmiths College, London and is currently a tutor in painting at The Royal College of Art, London.

E-mail: jesse.ash@rca.ac.uk

\begin{abstract}
This piece follows two demonstrations from London and Los Angeles. A decade apart, the protests are described at first hand (London) and via mediated sources such as uploaded videos to twitter (Los Angeles). In this article, I build upon the resistant capability of organization within networks of communication and isolate one of the products of this organization; the street protest, in terms of its sonorous form in contrast to both its physical (numbers of protesters, critical mass), or symbolic presence (slogans,
\end{abstract}


placards, banners). Using first person narrative, and examples such as the jangling of keys (Wenceslas Square, Prague, 1989), I take this murmur and buzzing of voices that declare a political intention as an opportunity to ask what the political identity of this public becomes when its symbolic meaning is 'denatured' (Barthes).

Charing Cross station, London. The underground system brings me back out into daylight. It is cold, and many shoppers walk between coffee shops, bus stops, train stations, and restaurants holding square, shiny bags. Think for a second of the sound here in this busy street. Think of the traffic first - buses with diesel engines, and purring cars waiting at lights - a deep, heavy background sound. And then, the sounds that are closer, like the scrape of a shoe heel on an uneven paving slab a metre in front, the single drum beat of a dropped bin being emptied, or the metronomic bleeping of a nearby reversing van. Think of those small bits of sound even quieter and closer - when you catch someone's conversation over their shoulder, waiting to cross the road-that rare moment when strangers stand close and still and then separate forever. In all this noise, resounding from a multitude of distances, there is a single whistle. And at this moment, standing with the buses, and the bins, and the shoppers - two worlds collide. Two groups of people merge sonorously - shoppers and demonstrators.

Today, our sight has dimmed; it no longer sees our future, having constructed a present made of abstraction, nonsense, and silence. Now we must judge a society more by its sounds, by its art, and by its festivals, than by its statistics. 
These collective murmurings in London represent opposing voices with their own distinct political identities and ideological territory - of those participating in a globalized system and those protesting against it. Like birdsong, the protesters announce their territorial occupation amidst an established landscape. This is not simply a call of presence - this territorial occupation defines the success or failure of any protest.

\begin{abstract}
All music, any organization of sound is then a tool for the creation or consolidation of a community, of a totality. It is what links a power centre to its subjects, and thus, more generally, it is an attribute of power in all its forms. Therefore, any theory of power today must include a theory of the localization of noise and its endowment with form. Among birds a tool for marking territorial boundaries, noise is inscribed from the start with the panoply of power. Equivalent to the articulation of space, it indicates the limits of a territory and the way to make oneself heard within it, how to survive by drawing one's sustenance from it. And since noise is the source of power, power has always listened to it with fascination.
\end{abstract}

(Attali [1977] 1985: 6)

Since the poll tax riots in London in 1990, the police have changed strategy in order to avoid losing control of the city centre (Campbell 2009). Since then, both at the May Day riot in 1990, and the G20 protests in the City of London in 2009, the strategy of 'kettling' was imposed. This method of physical containment aims to trap and contain protestors in splintered groups, isolate them from each other, to restrict the impact of a large physical mass and eventually wear down momentum. The method is similar to the tactics imposed for policing supporters at football matches. What is consistent between both contained groups is the use of the voice to perforate the enforced physical boundaries. The songs of away fans waiting for hours in stadia, at train stations, or outside the ground and the shouts and chants of 'kettled' protestors not only proclaim a collective identity through 
'one voice' but also, importantly, occupy territory inaccessible by foot. The relative immateriality of sound functions as an appropriate medium of action that can perforate solid borders and react to imposed physical segregation.

\section{Rattle of dissent and control}

\section{Pots, pans and keys}

Metropolitan Detention Centre, Downtown Los Angeles. As the protesters (@aguirran, 2016) look up to the Gotham City concrete block incarcerating prisoners and immigrants held before deportation they can see the lights in the windows flashing. The tiny grid of windows flashes out a Morse code to the demonstrators below. Prisoners calling out in solidarity. The protesters stop, look up and shout, scream, bang drums and honk horns in response. The flashing code is a kind of score for the crowd on the street. Those inmates who don't flash their lights bang metal objects on the walls or other surfaces to make a knocking sound that the protestors can hear. They are faceless but the building that imprisons them is their instrument to shout out to the city outside.

The sound of keys is a common, natural curiosity for a young child. There is a simple, physical relationship with the movement of the hand and the sound that is produced. This individual corporeal relationship between the body and sound was intensified collectively during the events leading to the Velvet revolution in Wenceslas Square, in Prague in November 1989. As Alexander Dubcek was brought out of hiding, Vaclav Havel spoke to the people of Czechoslovakia. Soviet rule was broken and the crowds of thousands rattled key chains and tiny bells in the central square. This jangling of keys symbolized the opening of previously locked doors (Tagliabue 2012) and had become a common act in the wave of protests in the crumbling Soviet states of Eastern 
Europe. The symbolic relation between instrument and political desire is again illustrated by the protests on the streets of Buenos Aries that took place in December 2002. As the economic collapse took place in Argentina and the government announced a state of emergency, a cross-class mass of a million people took to the streets, converging on the presidential palace and banging pots and pans (Adamovsky 2003). The protest was known as Cacerolazo (saucepans) - a movement identified by the instrument that produced its soundtrack.

Embankment, London. Following the direction of the whistle on foot brings more shrill toots and less traffic. These high-pitched sounds-expelled air from the lungs of bodies in the street - begin to engulf the humming puffs of diesel exhaust pipes. And then half way down a narrow alley, I stop and listen to the indecipherable merger between the low vocal hum ahead, and the mechanical rumbling from the road behind: almost indistinguishable, they form a huge heavy blanket of sound perforated by tiny sharp whistles. Walking towards the hum in front, the sound begins to break up softly, changing from a single blanket into a number of overlaid patches. With a sporadic rhythm, the sound starts to roll like water.

Sound is also used on the other side of the barricade in order to control and combat those who demonstrate. The megaphone is recognized as the classic tool to verbally direct individuals to comply an order. Aside from the use of amplified and forcefully directed words, sound in its purer form can be used for similar aims.

Humans can be physically affected by certain sounds or noises: very high frequencies or very loud sounds measured can damage hearing. Very low frequencies affect other areas of the body, and have commonly been used in torture - digestive systems can be disturbed, the functioning of the heart disrupted. Many types of sound can be mentally 
disturbing. To think of these effects is only to begin to see how noise works, and the element that links all noise, all judgments that noise is happening, is that noise is something that one is subject, submitted or subjected to.

(Hegarty 2007: 4)

In addition to techniques such as 'noise bombardment' being used against terrorist suspects in Guantanamo (Back 2007: 1), sound or noise - that which Hegarty terms as sound 'perceived negatively' (Hegarty 2007 3) continues to be used as a policing tool in urban areas. Following the 2009 G20 London Summit in the United Kingdom, the Pittsburgh Summit held in the United States only six months later presented examples of the use of sound as a public control device. On 24 and 25 September 2009, the Long Range Acoustic Device was used for the first time in the United States against its own citizens. The LRAD is a crowd-controlling device emitting a high-frequency sound beam capable of damaging the eardrum and causing permanent damage. The LRAD has been used around the world on war ships and in Iraq. It was at hand at the Republican National Convention in New York City, 2004 and used against opposition protesters in Tbilisi, Georgia by Russian forces as well as privately by the Luxury cruise ship, Seaborne Spirit, to defend against Somali Pirates in November 2005. The device can be used both as a physical deterrent causing pain or imbalance, or alternatively, as an incredibly precise megaphone able to reach long distances and very specific targets. Curiously, the same device has also been used in shopping malls (www.thefreelibrary.com) to 'aim' specific offers to customers at particular geographic locations within the shop or supermarket. The LRAD acts then as an advanced form of sonorous control - both as a tool to project words of temptation to consumers or to fire sound capable of disabling those who protest against global consumerism. The Mosquito Anti-Social Device (MAD) omits a high- 
frequency $(16-20 \mathrm{kHz})$ sound only perceptible to the ears of those less than 25 years old. Goodman (2010: 183) explains how this 'unsound' can be used to selectively deter groups of teenagers from shopping centres and street corners where they are not wanted.

3rd Street tunnel, Los Angeles. The camera frames the tunnel (Zukin, 2016) as a central orifice sucking in human bodies. The concrete walls are cracked like the folds of an internal organ, giant intestine or anus. A large group of people holding placards walk towards its dark centre. The camera mic picks up the echo of the tunnel, a hazy sound of shouts that notates a gasping reverberating rhythm at the mouth of this black hole. Protesters flow past the camera, showing the backs of heads as they move forward together, away from the camera, into the dark space ahead.

\section{The 'rustle' of demonstration}

[...] There always remains too much meaning for language to fulfil a delectation appropriate to its substance. But what is impossible is not inconceivable: the rustle of language forms a utopia. Which Utopia? That of a music of meaning; in its utopic state, language would be enlarged, I should even say denatured to the point of forming a vast auditory fabric in which the semantic apparatus would be made unreal; the phonic, metric, vocal signifier would be deployed in all its sumptuosity, without a sign ever becoming detached from it (ever naturalizing this pure layer of delectation), but also and this is what is difficult without meaning being brutally dismissed, dogmatically foreclosed, in short castrated.

(Barthes [1967] 1989: 77)

Millbank, London. Back on the street and closer to the demonstration, there's suddenly more definition. Low and high pitches attach themselves to these overlaid patches of sound, and for the first time, the sound of voices is recognizable. But, there are still no words yet. The shouts are still muffled, cried out in rhythm together, and as these sounds 
get louder and louder they follow each other, keeping in time together or responding to an unidentifiable distant single call. Here, approaching the voices, text on banners and placards announce intentions and anger, opposition and alliance, yet still the words in these voices are hard to find. Closer still, as I walk towards this mass of sound, text repeats and repeats on leaflets that appear again and again, on the floor, stuck on walls, left on benches and pressed into open slits on lamp posts. These leaflets are passed between hands too; confirming 'Guilt', 'Murder', 'Lies'. Words hastily printed, spluttering onto primary coloured paper rectangles. These leaflets, with the sound of words shouted by the mouths alongside them, bring to mind the outpouring of verbal expression on the streets during the French Revolution and the printed journals and pamphlets that accompanied them with titles such as 'bouche' (mouth), 'voix' (voice), and 'cri' (cry).

Within this demonstration, there is a vast constituency of allegiances. We march 'together' and at the same time we walk alongside each other separately, as inevitably our politics do not marry universally. These individual subjectivities are announced through placards, imagery, text and words, but from a distance, these voices together produce a collective hum of togetherness. This sound represents the unification of thousands of voices - a live, temporal, collective act. From afar, the fragmented subjective identities are hidden, and a public occupation of territory is announced. But this is not only an occupation of real physical space, in real time, in a capital city centre - this moment also activates a mass occupation of language.

At this stage in the march, words are hidden amidst the rustle of the sound of the demonstration. Crucially, following Barthes above, these individual words have not been 
lost or expelled; they still constitute the hum or rustle, but they cannot be recognized as words themselves. They are dormant threads within a vast fabric. They are not detached from the overlaid medium of the voices; they are very much part of it.

Roland Barthes describes this moment where individual words are lost amidst a collective rumble of voices as the concealment of the 'symbolic aggressor'. He suggests that the absence of subjective deviation presents a 'linguistic utopia' free from the distraction of the signifier; a language that reveals the form and presence of the speaker's language, but not its specific meaning. The rustle is the sound of the presence of language, not the specific constituents of it.

Barthes uses an example of the sound of overheard foreign language, where 'the meaning was doubly impenetrable to me' but 'I was hearing the music, the breath, the tension, the application' (Barthes [1967] 1989: 78-79). Contrary to Hegarty's perorative reference to loud conversations as nuisance noise (Hegarty 2007: 3), Barthes sees these overheard words as a unique moment where language is truly being itself.

In general terms, Barthes sees the inevitable mis-firing of language as a perpetual game of failed catch-up. Every verbal addition that endeavours to undo what has already been said becomes another failure, and so words seem to be perpetually 'stammering'. Interestingly, he likens this to the noise of a malfunctioning machine. Again, noise is used pejoratively (malfunction) and rustle is used positively, to describe a machine working well - in this case the sound of 'the enormous rustle of the little balls' (Barthes [1967] 1989: 77) in huge pachinko halls in Japan. The vast pachinko gambling halls with line after line of slot machines represent the sound of the mass surrender to the economic desires that spectacle (Debord [1973] 1994) provides and promotes. There are no voices 
in the Pachinko halls, as with the vast gambling halls in Las Vegas. If voices are present at all, they are drowned by the sound of the games, leaving the ears with a 'ringing' sound that follows you when you go to your hotel room or even resonating in the eardrum on the plane home. Indeed, this is a performative 'community of bodies: in the sounds of the pleasure which is "working," no voice is raised, guides, or swerves, no voice is constituted; the rustle is the very sound of plural delectation - plural but never massive (the mass, quite the contrary, has a single voice, and terribly loud)' (Barthes [1967] 1989: 77). Barthes' examples of the rustle are limited to both the Pachinko halls where there are no voices and the incomprehensible overheard foreign conversations. Both these examples are already linguistically inaccessible to the hearer, as firstly, there are no words spoken (Pachinko halls), and secondly, there is no identifiable vocabulary present (unfamiliar foreign languages).

3rd Street tunnel, Los Angeles. Drums, chanting in rhythm and the sound of clapping echo round this sound chamber. Another instrument of the city, usually amplifying the low deep hum of engines and now temporarily occupied to pronounce the rumble of voices shouting together. The camera (Bermudez 2016) circles 360 degrees as it enters the tunnel showing the numerous cameras that document this movement of people. The guts of the city resonate sounds expelled from the lungs and larynxes of human bodies moving like bacteria through the city system.

Barthes describes the mass as 'loud' but the mass is only loud when you are close to it. Its 'rustling' depends on distance or the echoing mutation in the tunnel where the sound of voices gets diluted and absorbed by the medium through which it travels. The recognition of the sound of the mass from afar in London, or muffled in its own echo in 
Los Angeles, reveals a kind of rustling protest. Demonstrations are temporal fluid things both physically and acoustically, occupying varying geographical spaces. And as the individual moves in and out of the mass, or we witness the camera travelling towards and through the protest, the emanating sound is 'denatured' by the body, the city's architecture and the smartphone.

\title{
Listening to internal voices
}

\begin{abstract}
What secret is at stake when one truly listens, that is when one tries to capture or surprise the sonority rather than the message? What secret is yielded - hence also made public when we listen to a voice, an instrument, or a sound just for itself? And the other indissociable aspect will be: What does to be listening, to be all ears, as one would say 'to be in the world', mean? What does it mean to exist according to listening, what resonates in it, what is the tome of listening or its timbre? Is even listening itself sonorous?.
\end{abstract}

(Nancy 2007: 5).

The first words we hear as humans are those of our parents, but this occurs before the comprehension of language and even before birth. The first encounter we have with words is the muffled sound of speech from the womb. The words of the mother are produced at the greatest proximity to the baby's sensory receptors within the womb. The resulting sounds are not only identified by the tone of voice but are also dependent upon a corporeal mediality - how these sounds travel through and reverberate with fluids, organs, voice box, lungs and skin. In a sense, these first words we encounter could be described as an encounter with the mediality of language, where meaning is absent and is therefore defined by its form.

Parliament Sq., London. Up close now, walking next to those who shout with voices projected from their mouths I can hear the way the words are shouted as much, or 
if not more, than I can hear the words themselves. I stand near the caller and hear the rasping dryness of his throat as he shrieks, it sounds like it hurts. It's a rough sound that is almost stringy - a vocal chord. It's about to snap. Break. Hoarse and rough, throbbing larynx, inflamed tonsils, it sounds as if it could disappear into an empty projection of air at any moment, like a hissing serpent - the sound of speech when the voice box is removed. And then, after listening to the internal workings of the caller, I hear the ligaments and cartilages of proclamation, and imagine the strained colour of this vocal excertion. At this moment, I can hear his voice, and those around me, but above all I can hear these voices resonating within me, in a sort of internal rumbling of reception. I can hear these words in my ears but I can also feel the reverberations deep in my stomach. Moreover, the sound that penetrates through the ear propagates through the entire body something of its effects, which could not be said to occur in the same way with the visual signal. And if we note also that 'one who emits a sound hears the sound he emits', one emphasizes that animal sonorous emission is necessarily also (here again, most often) its own reception.

(Nancy 2007: 15).

We require an external tool such as a mirror to make us aware of when we are in the process of seeing, whereas listening lets us know we are listening through a physical reverberation within our body. As we cannot close our ears as we can our eyes, this sensory self-reflexivity continuously announces our own presence to ourselves. This exchange or return (renvois) describes a site of both sonorous emission and reception (listening) occurring at the same time, and 'it is precisely from one to the other that it "sounds"' (Nancy 2007: 16). This 'sounding' proclaims our individual and collective presence and as we follow these shouts from the streets of London, hear the Tweeted 
echoes of the 3rd Street tunnel and the call and response Morse code from the

Metropolitan Detention Centre in Los Angeles we are shouting out our most powerful slogan that says to those we protest against, to each other and to ourselves that 'WE ARE HERE'.

This piece is a re-edited version of a chapter written for my Ph.D. thesis 'The figure of speech - The politics of contemporary chatter'. It combines a narrative account of my participation in an anti-G20 demonstration in London in 2009 with my responses to online posts by members of the public attending anti-Trump protests in Los Angeles in 2016.

\section{References}

Adamovsky, Ezequiel (2003), 'Pots, pans and popular power: The neighbourhood assemblies of Buenos Aries' in We Are Everywhere: the irresistible rise of global anticapitalism, edited by Notes From Nowhere. London/New York. Verso, p422427. www.artactivism.gn.apc.org/allpdfs/422Pots\%20Pans\%20and\%20Popular.pdf. Accessed 27 November 2009.

@aguirran (2016), 'From the streets of Los Angeles@aguirran', Twitter, 10 November, https://twitter.com/aguirran/status/796658104528084992. Accessed 6 September 2017.

Attali, Jacques ([1977] 1985), Noise: The Political Economy of Music, Manchester: Manchester University Press.

Back, Les (2007), The Art of Listening, London: Bloomsbury. 
Barthes, Roland ([1967] 1989), The Rustle of Language, Berkeley: The University of California Press.

Bermudez, Ezmeeralda (2016), 'Protesters enter the 3rd Street tunnel. @LATbermudez', Twitter, 12 November, https://twitter.com/LATbermudez/status/797528935206522881. Accessed 7 September 2017.

Business Wire, (2006) 'New directional sound system debuted by American technology corporation at InfoComm06', The Free Library, 8 June, http://www.thefreelibrary.com/New Directional Sound System Debuted by American Technology...-a0146776690. Accessed 4 January 2010.

Campbell, Duncan (2009), 'Did the handling of the G20 protests reveal the future of policing?', The Guardian, 3 April, 2009

www.guardian.co.uk/world/2009/apr/03/g20-protests-police-kettling. Accessed 30 November 2009.

Debord, Guy ([1973] 1994), The Society of the Spectacle, New York: Zone Books.

Goodman, Steve (2010), Sonic Warfare: Sound, Affect, and the Ecology of Fear, Cambridge, MS and London: MIT Press.

Hegarty, Paul (2007), Noise/Music: A History, New York: Continuum.

Nancy, Jean-Luc (2007), Listening, New York: Fordham University Press.

Tagliabue, John (2012), 'Upheaval in the East; from all Czechoslovakia, a joyful noise', The New York Times, $12^{\text {th }}$ December, 1989 www.nytimes.com/1989/12/12/world/upheaval-in-the-east-from-all- 
czechoslovakia-a-joyful-noise.html?scp=5\&sq=\&pagewanted=2. Accessed 27

November 2009.

Zukin, Meg (2016), ‘Footage from yesterday. @ bymeg', Twitter, 13 November, http://twitter.com/bymeg/status/797891211658833920. Accessed 6 September 2017.

Jesse Ash has asserted his right under the Copyright, Designs and Patents Act, 1988, to be identified as the author of this work in the format that was submitted to Intellect Ltd. 